\title{
Whither abortion policy in Britain?
}

\section{Ellie Lee}

\section{Correspondence to}

Dr Ellie Lee, School of Social Policy, Sociology and Social Research (SSPSSR), Cornwallis $\mathrm{NE}$, University of Kent, Canterbury CT2 7NY, UK; E.J.Lee@kent.ac.uk

Received 12 September 2012 Revised 29 October 2012 Accepted 2 November 2012
To cite: Lee E. Journal of Family Planning and Reproductive Health Care 2013, 39, 5-8.

\section{OVERVIEW}

This commentary discusses the current situation regarding Government policy on abortion in Britain. It begins by setting out the ways in which the policy of the Coalition Government appears to differ from that of the New Labour administration. The article notes that 2012 brought furious debate about abortion services, focusing on counselling, 'sex-selection' abortion, signing of HSA1 forms and, most recently, the upper time limit, and discusses what has emerged to date from these furores. Finally, thoughts are offered on how to respond to the problems raised by the current approach of policymakers.

\section{ABORTION POLICY}

Under the New Labour government, in a departure from any previous policy modus operandi, an explicit 'sexual health policy' emerged. The two central programmes developed were the Teenage Pregnancy Strategy and the National Strategy for Sexual Health and HIV. It would be going too far to say a specific 'abortion policy' emerged as part of this, but the framework for abortion provision did evolve as part of this Government interest in 'sexual health'. Taking the Royal College of Obstetricians and Gynaecologists (RCOG)'s evidence-based guidelines published from 2000 as a reference point, ${ }^{1}$ policy encouraged a set of linked developments.

There was a shift in the timing of abortion procedures. The distribution of procedures between the first and second trimesters did not change, with the latter consistently constituting around 10\% of procedures; but within the first trimester the distribution shifted to an increased proportion at under 9 weeks. The proportion of procedures performed using early medical abortion (EMA) increased. A larger proportion of women accessed abortions funded by the Department of Health; and independent sector providers provided a growing proportion of statefunded procedures under contract. $^{2}$
While it is important not to overstate the role of policy in shifting abortion provision in these ways (the providers themselves have taken the initiative), it may be argued that there was a policy framework facilitative of these changes.

These shifts, however, occurred in the context of there being no change to the law. Indeed, there was clear official antipathy to measures or arguments that could be construed as 'liberalising' or seeking to make abortion 'easier' under the law. Most notably, the chance to bring about important changes to the law through the 2008 debate about the Human Fertilisation and Embryology Bill was clearly rejected by the New Labour policymakers. ${ }^{3}$ At the end of the period of New Labour Government in 2010, abortion was more accessible than previously, but under a policy framework based on a very different rationale for provision than one of increasing reproductive choice.

A way to characterise this policy approach is as 'abortion pragmatism'. Abortion was viewed officially as a measure of 'poor sexual health', and an increasing abortion rate consistently represented by policymakers as troubling. At the same time it was understood that abortion that would have to be tolerated, and provided in a cost-effective way, especially given the policy trajectory presenting teenage motherhood as a disaster for all concerned. 'Abortion pragmatism' meant a policy that improved access to abortion could sit alongside a politics estranged from the idea of reproductive choice.

\section{DISPARAGING THE ABORTION SERVICE}

The most recent statistics indicate these developments in abortion provision have continued, in the context of a different Government. In 2011 (in England and Wales), $96 \%$ of abortions were NHS-funded; 91\% were carried out at under 13 weeks gestation and $78 \%$ at under 9 weeks (compared to $58 \%$ in $2001)$; and $61 \%$ took place in the independent sector under contract (up from 
$59 \%$ in 2010). ${ }^{4}$ Yet this continuation of previous trends has taken place against a different policy framework, raising questions about whether it will continue.

At the time of writing (November 2012) there is what is best described at present as a policy vacuum. The Teenage Pregnancy and Sexual Health and HIV strategies came to an end in 2010 but no subsequent sexual health policy has been published. Rather, the following short statement has appeared on the Department of Health website since 2011:

"As stated in the White Paper Healthy Lives, Healthy People the Government will work towards an integrated model of service delivery to allow easy access to confidential, non-judgemental sexual health services, including for sexually transmitted infections, contraception, abortion, health promotion and prevention. A new sexual health policy document is due to be published in 2012."

Healthy Lives, Healthy People, published in November 2010, includes little comment on 'sexual health' and none whatsoever on abortion. ${ }^{5}$ The only place in the document where sexual health is specifically mentioned is in discussion of 'growing up':

"Teenagers and young people are amongst the biggest lifestyle risk-takers... Teenage conceptions are at a 20-year low ... but are still high compared with Western Europe ... As young people move through their teenage years and make the transition into adulthood, our aim is to strengthen their ability to take control of their lives... and help reduce their susceptibility to harmful influences, in areas such as sexual health, teenage pregnancy, drugs and alcohol."

It can be argued this approach is consistent with themes in previous policy, in its representation of teenage sex and intimate experience as 'risk-taking', where 'risk' is made coterminous with being harmed. ${ }^{6}$ However, there does not appear to be evidence that the abortion pragmatism that went along with this previously now remains. Rather, abortion so far has been represented by health ministers in the Coalition Government as both a sign of the failure of desirable risk-management and also as itself a form of 'harm'.

The then Public Health Minister Anne Milton expressed this relation between risk-taking in heterosexual sex and the harm of abortion this way, in a press statement in May 2012:

"Having an abortion can be traumatic and stressful and should never be seen as a form of contraception... We want both men and women to think carefully before having sex."

It is this re-framing of abortion, as a measure of the harm done by sexual 'risk taking', that is probably the most distinct theme of the Coalition's approach.

Recent episodes in debates about the abortion service provide further indications of the way that
Government ministers appear to view the issue. One is the debate over 'independent abortion counselling'. Since early 2011, the claim that the Government should change the way abortion counselling is provided, by taking the counselling role away from abortion providers, has been raised repeatedly by the Conservative MP Nadine Dorries, with support given by Labour's Frank Field to her proposed (and defeated) amendment to the Health and Social Bill in Autumn 2011. More recently, in Spring 2012, debate focused on accusations emanating in the first place from the Daily Telegraph that abortion providers were authorising and providing 'sex selection' abortions, and then on providers' processes and procedures for signing HSA1 forms.

These debates as they developed appeared to spring from nowhere; this was especially true of the 'sex selection' debate. On closer examination, however, they can be understood as continuing a long-running effort on the part of those opposed to abortion to limit and constrain its provision. It was a phase of debate that began in 2004, when it became clear that a Parliamentary review of the Human Fertilisation and Embryology Act could present an opportunity to re-open the debate on abortion. Since this point, two themes have become prominent in anti-abortion discourse: first, the representation as abortion providers as 'villains' - uncaring, self-interested, aloof from the reality of abortion, and ignorant of the value of life; and second, that when it comes to abortion, women (and/or girls) are 'victims', traumatised and ill-treated through their experience, including at the hands of abortion providers.

Coalition Government ministers have so far, notably, either not contradicted, or have actively encouraged, these representations of what abortion provision is all about. For example, it was striking that in October 2012, Maria Miller, the newly appointed minister for women and Secretary of State for Culture, Media and Sport, defended her view that the upper limit for abortion should be brought down by arguing she was, "riven by that very practical impact that late term abortion has on women", implying that those who provide such abortions care little for women and their feelings. ${ }^{8}$ In the earlier Parliamentary debate on counselling as part of the Health and Social Care Bill in September 2011, Anne Milton, then Public Health Minster, argued that the Dorries/Field amendment should be rejected on a range of procedural grounds, but that a consultation on the provision of abortion counselling should be established nonetheless. She argued, with reference to the claims of those hostile to abortion providers:

"We have heard passionate contributions this afternoon, and I want to harness and corral them to create the calm and balance that we all want to be established ... the Government supports the spirit of the 
amendments, and we intend to present proposals for regulations after consultation." ",

This endorsement of the 'spirit' of the Dorries/Field reasoning, it being that abortion providers cannot be trusted to work in women's best interests, was further endorsed by representatives of the Government in February 2012, when the then Secretary of State for Health Andrew Lansley made an unprecedented intervention into the Daily Telegraph's investigation into 'sex selection' abortions. Lansley wrote that there are "real concerns" about what the abortion service is doing, that "abortion is a life-changing decision", and that the Government will be consulting "on counselling arrangements for women seeking an abortion". Strongly supporting the allegation that abortion providers were "opting out of" the law, Lansley chose to announce in the pages of the Daily Telegraph that the Care Quality Commission were to be "investigating a number of abortion clinics"10 (an investigation that went ahead, resulting in the CQC finding "irregularities" at only a small number of clinics, none of them in the independent sector). ${ }^{11}$

\section{WHAT POSITIVE CHANGES COULD POLICYMAKERS EFFECT?}

In early November 2012 it was announced that the consultation on abortion counselling will not be going ahead, with the new Health Minister Anna Soubry describing it as an "otiose exercise". ${ }^{12}$ This hopefully means at least no more time and money will be spent on debating unnecessary and unhelpful changes to the abortion service. Insofar as there is any opportunity to encourage the policymakers now around the Coalition Government to think in a better way than their predecessors about what an abortion policy needs to do, there is no need look further than the conclusions and recommendations of the House of Commons' Science and Technology Committee's enquiry into the 1967 Abortion $\mathrm{Act}^{13}$ and the programme for change developed by the group led by Evan Harris MP during the 2007/2008 debates about reform of the Human Fertilisation and Embryology Act. ${ }^{14}$ These proposals focused on policy modernising abortion provision, in particular through the removal of the requirement for two doctors' signatures before an abortion can be carried out, which can cause delays in access to abortion services and has no value in terms of safety; permitting nurses and midwives with suitable training to carry out all stages of EMA and early surgical abortion, which would increase access to abortion at the earliest stages without compromising safety or quality of care; and enabling women, who choose to do so, to take the second stage of EMA at home.

However, it seems likely to be just as important to find ways to limit change and keep policymakers out of abortion services, leaving providers to get on with it, in line with their experience and professional know-how. This 'stay away' message needs to continue to be pressed in relation to abortion counselling, the present modus operandi of which (where counselling is mainly provided in-house) has emerged over many years of debate and experience. ${ }^{15}$ Looking forwards, the most constructive approach can be captured by the phrase "If it ain't broke, don't fix it". The abortion service has a lot to be proud of and it matters that policymakers come to know this.

Funding None.

\section{Competing interests None.}

Provenance and peer review Commissioned; externally peer reviewed.

\section{REFERENCES}

1 Royal College of Obstetricians and Gynaecologists. The Care of Women Requesting Induced Abortion. 2011. http://www.rcog. org.uk/womens-health/clinical-guidance/care-womenrequesting-induced-abortion [accessed 24 October 2012].

2 Lee E, Ingham R. Why do women present late for abortion. Best Pract Res Clin Obstet Gynaecol 2010;24:479-489.

3 Hansard. HFE Bill 2008 debate on 22 October 2008 Column 324. http://www.publications.parliament.uk/pa/cm200708/ cmhansrd/cm081022/debtext/81022-0006.htm [accessed 24 October 2012].

4 Department of Health. Abortion Statistics, England and Wales: 2011. 2012. https://www.wp.dh.gov.uk/transparency/files/2012/ 05/Commentary1.pdf [accessed 24 October 2012].

5 Department of Health. Healthy Lives, Healthy People. 2010. http://www.dh.gov.uk/en/Publicationsandstatistics/Publications/ PublicationsPolicyAndGuidance/DH_121941 [accessed 24 October2012].

6 Hoggart L. 'I'm pregnant ... what am I going to do?' An examination of value judgements and moral frameworks in teenage pregnancy decision making. Health Risk Soc 2012;14:533-549. http://dx.doi.org/10.1080/13698575.2012. 706263 [accessed 24 October 2012].

7 Statement on abortion by Public Health Minister, Anne Milton, made to accompany the release of the 2011 abortion statistics. [NB. The comment does not now appear on the relevant Department of Health webpage.] http://mediacentre.dh.gov.uk/ 2012/05/29/abortion-statistics-england-wales-2011/ [accessed 24 October 2012].

8 Collins N. Maria Miller: I would vote to lower abortion limit from 24 to 20 weeks. The Telegraph, 3 October 2012. http:// www.telegraph.co.uk/women/womens-politics/9581895/MariaMiller-I-would-vote-to-lower-abortion-limit-from-4-to-20weeks.html [accessed 24 October 2012].

9 Hansard. House of Commons Debate on the Health and Social Care Bill. 7 September 2012. http://www.publications. parliament.uk/pa/cm201011/cmhansrd/cm110907/debtext/ 110907-0002.htm [accessed 24 October 2012].

10 Andrew Lansley: abortion clinics will be inspected. The Telegraph, 23 March 2012. http://www.telegraph.co.uk/health/ healthnews/9162373/Andrew-Lansley-abortion-clinics-will-beinspected.html [accessed 9 November 2012].

11 BBC News Online. Abortion clinic inspections find 14 'broke the rules'. 12 July 2012. http://www.bbc.co.uk/news/health18811705 [accessed 9 November 2012].

12 Usherwood T. Abortion review counselling axed. The Independent, 31 October 2012. http://www.independent.co.uk/ 
news/uk/politics/abortion-counselling-review-axed-8269169. html [accessed 31 October 2012].

13 House of Commons Science and Technology Committee. Scientific Developments Relating to the 1967 Abortion Act. Twelfth Report of Session 2006-07. Volume I. 2007. http:/ www.publications.parliament.uk/pa/cm200607/cmselect/ cmsctech/1045/1045i.pdf [accessed 24 October 2012].
14 Voice for Choice. Briefing for MPs - Amendments to modernise the 1967 Abortion Act. http://vfc.org.uk/wpcontent/uploads//2008/10/vfc-briefing-modernising-the-1967abortion-act.pdf [accessed 24 October 2012].

15 Lee E. Pregnancy counselling in Britain, a review of the literature. Abortion Review, 29 June 2011. http://www.abortionreview.org/ index.php/site/article/992/ [accessed 24 October 2012]. 